\title{
HUBUNGAN TINGKAT RELIGIUSITAS TERHADAP INTENSITAS KENAKALAN REMAJA ANAK SEKOLAH DI SMK YBKP3 GARUT
}

Iwan Shalahuddin1, Ahmad Yamin², Umar Sumarna ${ }^{3}$

Email : shalahuddin@unpad.ac.id

1,2,3Fakultas Keperawatan Universitas Padjadjaran Bandung, Jawa Barat, Indonesia

\begin{abstract}
Juvenile delinquency among high school students is the result of those who have issues in mental or psychological development. The aim of this study is to relationship between religiosity and intensity of juvenile delinquency among high school students. This study used quantitative approach and the design applied was product-moment correlation. For bivariate analysis purposes, one-way ANOVA was used to test compare mean. The total population of this study was 387 teenage students who have both good and bad behavior in terms of religiosity. The instrument used had been valid with the value of point biseral correlation from 0.126 to 0.617 with the alpha of 0.05 . The reliability value obtained was alpha 0.80 . The results showed that there was no difference between the religious level and the anger level based on the student's age ( $P$-value $)=0.967$, student class $(0.976)$ and gender (0.991). The conclusion obtained is that the religious level of students obtained is high or good as many as 192 students (49.6\%). This shows that the subject believes and believes in things that are fundamental and dogma in religion. Recommendations are given to always maintain well-applied arrangements, and need to be developed to correct all deficiencies and mistakes in an effort to prevent delinquency among school children.
\end{abstract}

\section{ABSTRAK}

Perilaku menyimpang pelajar adalah kenakalan pelajar yang biasanya dilakukan oleh pelajar-pelajar yang gagal dalam menjalani proses-proses perkembangan jiwanya. Tujuan penelitian Untuk mengetahui hubungan tingkat religiusitas terhadap intensitas kenakalan remaja anak sekolah. Penelitian ini menggunakan pendekatan kuantitatif korelasi dengan design Korelasi Product-Moment. Untuk analisa Bivariat menggunakan uji compare mean dengan one way ANOVA. Populasi penelitian ini remaja anak sekolah yang mempunyai religiusitas yang mana berprilaku baik maupun berprilaku buruk sejumlah 387 siswa yang dilakukan secara total populasi. Instrumen yang digunakan yang sudah baku yang telah memiliki hasil uji validitas tersendiri, (point biseral correlation) 0.126 sampai dengan 0.617 dengan alpha 0.05. Uji Reliabilitas dengan nilai alpha 0.80 . Hasil penelitian menunjukan tidak adanya perbedaan antara tingkat religius dengan tingkat kenakalan berdasarkan usia siswa $(P$-value $)=0,967$, kelas siswa (0.976) dan jenis kelamin (0,991). Kesimpulan yang didapat adalah tingkat religius siswa yang didapatkan adalah tinggi atau baik sebanyak 192 siswa $(49,6 \%)$. Hal ini menunjukkan bahwa subjek meyakini dan mempercayai hal-hal yang sifatnya fundamental dan dogma dalam agama. Rekomendasi yang diberikan untuk selalu mempertahankan tatanan-tatanan yang sudah diaplikasikan dengan baik, dan perlu dikembangkan untuk memperbaiki segala kekurangan dan kesalahan dalam upaya mencegah terjadinya kenakalan remaja anak sekolah.

\section{Pendahuluan}

Masa remaja merupakan masa pergantian atau transisi dari masa anak-anak menuju masa dewasa. Masa ini dianggap sebagai masa-masa yang penting dalam kehidupan seseorang, khususnya dalam pembentukan kepribadian seseorang. Pada masa transisi inilah yang menjadikan emosi remaja kurang stabil. Sehingga tidak jarang menemui remaja yang melakukan perilaku negatif dan penyimpangan. Perilaku penyimpangan ini bisa menyimpang dari norma hukum, norma agama dan norma yang dianut masyarakat. Masyarakat biasa menyebutnya dengan istilah kenakalan remaja (1).

Banyak faktor yang mempengaruhi perilaku, salah satunya menurut Jensen (2) mengatakan bahwa kenakalan remaja disebabkan karena remaja lebih mementingkan faktor individu dibandingkan dengan faktor lingkungan (Rational choice). Kenakalan remaja yang dilakukannya itu adalah atas kemauanya sendiri. Misalnya kenakalan remaja disebabkan karena kurangnya iman dalam diri remaja itu sendiri.

\section{ARTICLE INFO}

Keywords:

Juvenile Delinquency Intensity; Students; Religious Level

DOI:

Kata kunci :

Intensitas Kenakalan Remaja; Siswa; Tingkat Religiusitas 
Populasi remaja di Indonesia menurut Badan Pusat Statistik (BPS) per Februari 2017, rentang usia 15-19 tahun sebanyak 13.102.011 juta penduduk. Kemudian menurut data dari BPS Provinsi Jawa Barat, total penduduk dalam rentang remaja dalam usia 10-19 tahun pada tahun 2015 di Jawa Barat telah mencapai 8.471.022 juta jiwa dan berdasarkan proyeksi penduduk pada tahun 2017-2019 penduduk di Jawa Barat dengan rentang usia 10-19 tahun akan bertambah sebanyak 504.789 penduduk. Kabupaten Garut berdasarkan data BPS Kabupaten Garut pada tahun 2014, rentang usia 10-19 tahun mencapai 504.789 penduduk. Berdasarkan data-data diatas dapat dilihat angka laju pertumbuhan penduduk usia remaja yang sangat cepat, dengan demikian diperlukan adanya kegiatan yang bermanfaat dan arahan yang tepat bagi para remaja terutama remaja anak sekolah sebagai generasi penerus pelaksana tujuan pembangunan nasional. Jika hal ini tidak diantisipasi maka akan menimbulkan kenakalan-kenakalan remaja yang merusak masa depan dirinya juga dapat menghambat dalam pencapaian pembangunan nasional.

Saat ini generasi muda khususnya remaja zaman sekarang, telah digembleng berbagai disiplin ilmu. Hal itu tak lain adalah persiapan mengemban tugas pembangungan pada masa yang akan datang, masa penyerahan tanggung jawab dari generasi tua ke generasi muda. Sudah banyak generasi muda yang menyadari peranan dan tanggung jawabnya terhadap negara. Pada umunya kenakalan remaja ini dilakukan oleh anak yang berumur antara 15-18 tahun. Masa remaja anakn sekolah merupakan masa dimana sedang beralihnya masa anak-anak menuju masa kedewasaan.

Pada masa ini jiwa mereka masih labil dan mereka tidak memiliki pegangan yang pasti. Mereka berbuat sesuai dengan pikiran dan nalar, perbuatan itu mereka lakukan dalam mencari jati diri mereka sebenarnya. Kenakalan remaja itu harus diatasi, dicegah dan dikendalikan sedini mungkin agar tidak berkembang menjadi tindak kriminal yang lebih besar yang dapat merugikan dirinya sendiri, lingkungan masyarakat dan masa depan bangsa. Masalah remaja sebagai usia bermasalah. Setiap periode hidup manusia punya masalahnya sendiri-sendir, termasuk periode remaja. Remaja seringkali sulit mengatasi masalah mereka (3).

Perilaku menyimpang pada remaja anak sekolah sangat sulit untuk ditentukan karena tidak semua orang menganut norma yang sama sehingga ada perbedaan mengenai apa yang menyimpang dan tidak menyimpang. Orang yang dianggap menyimpang berarti melakukan perilaku menyimpang terutama dikalangan pelajar atau siswa di suatu sekolah (4). Pelajar akan mengalami periode perkembangan fisik dan psikis sebagai berikut : masa pra-pubertas (12-13 tahun), masa pubertas (14-16 tahun), masa akhir pubertas. (17-18 tahun). Dan perilaku menyimpang pelajar adalah kenakalan pelajar yang biasanya dilakukan oleh pelajar-pelajar yang gagal dalam menjalani proses-proses perkembangan jiwanya, baik pada saat remaja maupun pada masa kanak-kanaknya (5).

Kecamatan Tarogong kidul merupakan salah satu kecamatan yang berada di Kabupaten Garut yang merupakan kecamatan penyokong ibu kota Kabupaten. Secara geografis di Kecamatan Tarogong Kidul terdapat pusat sarana Pasar induk dan terminal induk Kabupaten Garut yang memungkinkan terjadinya keluar masuk warga baik internal kabupaten maupun luar kabupaten Garut, sehingga tidak menutup kemungkinan akan terjadi tranformasi gaya hidup yang mempengaruhi lingkungan setempat, diantaranya gaya hidup keras dan perilaku yang berpotensi terjadinya kenakalan-kenaklan remaja. Selain pusat pasar dan terminal induk yang ada, juga terdapat banyak beberapa sekolah tingkat menengah atas negeri dan swasta yang didalam nya terdapat siswa-siswa yang berada pada usia remaja yang berpotensi terjadinya kenakalan-kenakalan remaja sebagai pengaruh dari lingkungan tersebut. Salah satu sekolah swasta yang ada diantaranya Sekolah Menengah Kejuruan YBKP3 Garut yang berdekatan dengan terminal dan pasar.

Berdasarkan penelitian pendahuluan menunjukan bahwa di sekolah SMK YBKP3 Garut pada setiap tahunnya selalu ada kejadian dalam bentuk kenakalan remaja anak sekolah. Menurut penuturan guru BP dan Wakil Kepala Sekolah bidang Kesiswaan mengatakan di sekolah SMK YBKP dari jumlah keseluruhan siswa sebanyak 387 orang, pernah adanya kejadian kenakalan 
remaja baik di sekolah maupun di luar sekolah diantaranya dalam bentuk pelanggaran peraturan dan kedisiplinan sebanyak 10\% (34 orang), membolos sekolah 5\% (17 Orang), mencorat coret lingkungan sekolah 5\% (17 orang), perilaku buliying 1,7\% (6 Orang), perilaku merokok 6,7\% (23 orang), tauran antar sekolah 0,88\% (3 orang) dan ada juga dugaan kehamilan $0,28 \%$ (1 orang).

Kenakalan remaja juga bisa dipengaruhi oleh religiusitas remaja. Diibaratkan jika remaja memiliki religiusitas rendah maka perilaku kenakalannya tinggi, dan sebaliknya semakin tinggi religiusitas maka semakin rendah tingkat kenakalan pada remaja. Mengapa demikian, karena ia memandang agama sebagai tujuan utama hidupnya sehingga ia berusaha mementingkan ajaran agamanya dalam perilakunya sehari-harinya. Anak-anak remaja yang melakukan kejahatan sebagian besar disebabkan karena lalai menunaikan perintah-perintah agama (6).

Pendapat ini diperkuat dengan pernyataan yang menuturkan bahwa individu melakukan suatu penyimpangan disebabkan karena fitrah iman yang ada pada setiap individu tidak bisa berkembang dengan sempurna atau imannya berkembang tetapi tidak bisa berfungsi dengan baik,sehingga menyebabkan individu melakukan perbuatan-perbuatan yang bersifat negatif atau menyimpang dari aturan-aturan yang berlaku di lingkungannya (7).

\section{Metode Penelitian}

Penelitian ini menggunakan pendekatan kuantitatif korelasi dengan design Korelasi ProductMoment, Populasi penelitian ini adalah remaja anak sekolah yang mempunyai religiusitas yang mana berprilaku baik maupun berprilaku buruk sejumlah 387 siswa yang dilakukan secara total populasi. Teknik pengumpulan data yang digunakan adalah: Keperpustakaan yaitu mencari informasi dari remaja yang dibutuhkan untuk penelitian yang terpilih menjadi populasi. Data dari internet atau dari sumber data lain; Observasi, peneliti melakukan pengamatan secara langsung baik terhadap kegiatan dan aktifitas religius dan intensitas kenakalan remaja tersebut di SMK YBKP3 Garut; Teknik wawancara, peneliti melakukan wawancara langsung kepada informan langsung atau subjek yaitu remaja anak sekolah.

Instrumen yang digunakan yang sudah baku yang telah memiliki hasil uji validitas tersendiri, (point biseral correlation) 0.126 sampai dengan 0.617 dengan alpha 0.05 . Uji Reliabilitas dengan nilai alpha 0.80. Analisis data dengan menggunakan deskriptif untuk membantu peneliti mendeskripsikan ciri-ciri variable-variabel yang di teliti atau merangkum hasil pengamatan penelitian yang sudah dilakukakan tanpa membuat kesimpulan berlaku secara umum. Dari variable yang diperoleh populasi dan sampel di atas. Statistik deskriptif berkaitan dengan kegiatan pencatatan, penyusunan dan penyajian dengan mendeskripsikan data-data dari hasil pengamatan. Selanjutnya data karakteristik responden dilakukan uji homogenitas dengan Lavene's test. Untuk analisa bivariat menggunakan uji compare mean dengan one way ANOVA.

\section{Hasil Penelitian}

Karakteristik responden pada penelitian ini adalah hampir seluruhnya berjenis kelamin perempuan yaitu sebanyak 308 siswa $(79,6 \%)$ dan hanya sebagian kecil berjenis kelamin lakilaki sebanyak 79 siswa (20,4\%), dengan usia kurang dari setengahnya berusia 17 tahun sebanyak 153 siswa $(39,6 \%)$ dan sebagian kecil berusia 15 tahun yaitu 50 siswa $(12,9 \%)$ serta kurang dari setengahnya siswa duduk pada kelas XII sebesar 166 siswa $(42,9 \%)$ dan sebagian kecil terdapat di kelas X yaitu 80 siswa $(20,7 \%)$.

Tabel 1. Hubungan Tingkat Religius dengan Tingkat Kenakalan Responden di SMK YBKP3 Garut Tahun 2020

\begin{tabular}{|c|c|c|c|c|c|c|}
\hline \multirow{2}{*}{\multicolumn{2}{|c|}{ Tingkat Religius }} & \multicolumn{2}{|c|}{ Tingkat Kenakalan } & \multirow{2}{*}{ Total } & \multirow{2}{*}{ P-Value } & \multirow{2}{*}{ OR 95\% CI } \\
\hline & & Tinggi & Rendah & & & \\
\hline \multirow{2}{*}{ Rendah } & $\mathrm{n}$ & 80 & 115 & 195 & 0,074 & 1,494 \\
\hline & $\%$ & 41,0 & 59,0 & 100 & & $(0,985-2,266)$ \\
\hline \multirow{2}{*}{ Tinggi } & $\mathrm{n}$ & 61 & 131 & 192 & & \\
\hline & $\%$ & 31,8 & 68,2 & 100 & & \\
\hline Total & $\mathrm{n}$ & 141 & 246 & 387 & & \\
\hline
\end{tabular}


$\%$ 36,4

63,6 100

Tabel 1. Menunjukan Hasil uji chi-kuadrat didapatkan bahwa tidak terdapat hubungan antara tingkat religius dengan intensitas tingkat kenakalan remaja anak sekolah dengan $\mathrm{p}$ value $(0,074)$ dan OR 95\%CI sebesar 1,494 yang berarti seseorang yang memiliki tingkat religius rendah memiliki resiko melakukan kenakalan sebesar 1,4 kali dibandingkan dengan tingkat regius yang tinggi.

Tabel 2. Perbedaan Tingkat Religius dengan Tingkat Kenakalan Responden berdasarkan jenis kelamin di SMK YBKP3 Garut Tahun 2020

\begin{tabular}{|c|c|c|c|c|c|c|}
\hline \multicolumn{7}{|c|}{ ANOVA } \\
\hline & & Sum of Squares & df & $\begin{array}{c}\text { Mean } \\
\text { Square }\end{array}$ & $\mathbf{F}$ & Sig. \\
\hline \multirow{3}{*}{$\begin{array}{l}\text { Tingkat } \\
\text { Religius }\end{array}$} & Between Groups & 0.007 & 1 & 0.007 & 0.000 & 0.991 \\
\hline & Within Groups & 23942.510 & 385 & 62.188 & & \\
\hline & Total & 23942.517 & 386 & & & \\
\hline \multirow{3}{*}{$\begin{array}{l}\text { Tingkat } \\
\text { Kenakalan }\end{array}$} & Between Groups & 3098.765 & 1 & 3098.765 & 48.141 & 0.998 \\
\hline & Within Groups & 24781.653 & 385 & 64.368 & & \\
\hline & Total & 27880.419 & 386 & & & \\
\hline
\end{tabular}

Berdasarkan tabel 2. menunjukan tidak adanya perbedaan antara tingkat religius dengan tingkat kenakalan berdasarkan jenis kelamin siswa. Hasil uji ANOVA dari tabel itu pada kolom Sig. diperoleh nilai $\mathrm{P}$ (P-value) $=0,991$. Dengan demikian pada taraf nyata $=0,05$ kita menerima Ho, sehingga kesimpulan yang didapatkan adalah tidak ada perbedaan yang bermakna antara tingkat religiusitas dengan tingkat kenakalan berdasarkan jenis kelamin siswa.

Tabel 3. Perbedaan Tingkat Religius dengan Tingkat Kenakalan Responden berdasarkan jenis kelamin di SMK YBKP3 Garut Tahun 2020

\begin{tabular}{|c|c|c|c|c|c|c|}
\hline \multicolumn{7}{|c|}{ ANOVA } \\
\hline & & Sum of Squares & df & Mean Square & $\mathbf{F}$ & Sig. \\
\hline \multirow{3}{*}{$\begin{array}{l}\text { Tingkat } \\
\text { Religius }\end{array}$} & Between Groups & 16.490 & 3 & 5.497 & 0.088 & 0.967 \\
\hline & Within Groups & 23926.027 & 383 & 62.470 & & \\
\hline & Total & 23942.517 & 386 & & & \\
\hline \multirow{3}{*}{$\begin{array}{l}\text { Tingkat } \\
\text { Kenakalan }\end{array}$} & Between Groups & 4.766 & 3 & 1.589 & 0.022 & 0.996 \\
\hline & Within Groups & 27875.653 & 383 & 72.782 & & \\
\hline & Total & 27880.419 & 386 & & & \\
\hline
\end{tabular}

Berdasarkan tabel 3. Menunjukan tidak adanya perbedaan antara tingkat religius dengan tingkat kenakalan berdasarkan usia siswa. Hasil uji ANOVA dari tabel itu pada kolom Sig. diperoleh nilai P (P-value) $=0,967$. Dengan demikian pada taraf nyata $=0,05$ kita menerima Ho, sehingga kesimpulan yang didapatkan adalah tidak ada perbedaan yang bermakna antara tingkat religiusitas dengan tingkat kenakalan berdasarkan usia siswa.

Tabel 4. Perbedaan Tingkat Religius dengan Tingkat Kenakalan Responden berdasarkan Kelas di SMK YBKP3 Garut Tahun 2020

\begin{tabular}{lcccccc}
\hline \multicolumn{7}{c}{ ANOVA } \\
& & Sum of Squares & df & $\begin{array}{c}\text { Mean } \\
\text { Square }\end{array}$ & F & Sig. \\
\hline Tingkat & Between Groups & 3.054 & 2 & 1.527 & 0.024 & 0.976 \\
Religius & Within Groups & 23939.462 & 384 & 62.342 & & \\
Tingkat & Total & 23942.517 & 386 & & & \\
Kenakalan & Between Groups & 1.694 & 2 & 0.847 & 0.012 & 0.988 \\
\hline
\end{tabular}




\begin{tabular}{lcccccc}
\hline \multicolumn{7}{c}{ ANOVA } \\
& Sum of Squares & df & $\begin{array}{c}\text { Mean } \\
\text { Square }\end{array}$ & F & Sig. \\
\hline Tingkat & Between Groups & 3.054 & 2 & 1.527 & 0.024 & 0.976 \\
Religius & Within Groups & 23939.462 & 384 & 62.342 & & \\
& Total & 23942.517 & 386 & & & \\
Tingkat & Between Groups & 1.694 & 2 & 0.847 & 0.012 & 0.988 \\
Kenakalan & Within Groups & 27878.725 & 384 & 72.601 & & \\
& Total & 27880.419 & 386 & & & \\
\hline
\end{tabular}

Berdasarkan tabel 4. menunjukan tidak adanya perbedaan antara tingkat religius dengan tingkat kenakalan berdasarkan kelas siswa. Hasil uji ANOVA dari tabel itu pada kolom Sig. diperoleh nilai $\mathrm{P}$ (P-value) $=0,976$. Dengan demikian pada taraf nyata=0,05 kita menerima Ho, sehingga kesimpulan yang didapatkan adalah tidak ada perbedaan yang bermakna antara tingkat religiusitas dengan tingkat kenakalan berdasarkan kelas siswa.

\section{Diskusi}

Menurut Jensen (2) juga mengatakan bahwa ada empat aspek kenakalan remaja: (1) Perilaku yang melanggar hukum. Seperti melanggar rambu-rambu lalu lintas, mencuri, merampok, memperkosa dan masih banyak lagi perilaku- perilaku yang melanggar hukum lainnya; (2) Perilaku yang membahayakan orang lain dan diri sendiri. Seperti kebut-kebutan dijalan, menerobos rambu-rambu lalulintas, merokok, narkoba dan lain sebagainya; (3) Perilaku yang menimbulkan korban materi. Seperti mencuri, memalak, merusak fasilitas sekolah maupun fasilitas umum lainnya dan lain-lain; (4) Perilaku yang menimbulkan korban fisik. Seperti tawuran antar sekolah dan atau berkelahi dengan teman satu sekolah dan lain sebagainya.

Berdasarkan hasil penelitian didapatkan sebagian besar didominasi pada tingkat intensitas kenakalan rendah 246 siswa (63,6\%). Hal ini berdasarkan karakteristik responden yang umumnya adalah remaja yang sedang berada dalam proses perkembangan identitas. Hal ini sejalan dengan penelitian lain yang menyatakan bahwa terdapat 2 proses dari pengembangan identitas remaja, yang pertama yaitu self-exploration dimana proses ini mencakup beberapa hal seperti jenjang pendidikan hingga karir, hubungan antar pasangan, peran keluarga dan proses identity-commitment, dimana kemampuan individu untuk memiliki keyakinan atau komitmen pada identitas personal secara menyeluruh (8).

Dalam proses eksplorasi dan pencarian identitasnya tersebut, para remaja cenderung menghabiskan banyak waktunya bersama dengan teman sebaya mereka (peer groups) dibandingkan dengan keluarganya masing-masing, dimana hal tersebut akan membuat mereka cenderung terlibat dalam perilaku berisiko (9). Pada masa ini remaja memiliki rasa keingintahuan yang besar terhadap segala sesuatu hal yang baru. Rasa keingintahuan yang besar ini membuat remaja menjadi suka untuk mencoba dan menjelajahi berbagai macam hal yang baru yang berujung pada hal yang positif ataupun negatif (10).

Analisis lain mengenai penyebab rendahnya kenakalan remaja pada hasil penelitian dikarenakan ada beberapa siswa yang bersikap faking good, mereka berpura-pura baik dalam menjawab instrumen penelitian. Berdasarkan tanggapan dari siswa tersebut, mayoritas siswa beranggapan bahwa hasil penelitian tersebut akan dilaporkan kepada guru pembimbing sehingga dikhawatirkan hasilnya akan mempengaruhi nilai akademik mereka. Hal inilah yang menyebabkan mereka dalam menjawab instrumen penelitian tidak sesuai dengan keadaan yang ada dalam diri mereka sehingga hal tersebut berpengaruh terhadap hasil penelitian. Berdasarkan penjelasan tersebut, kenakalan remaja pada siswa tergolong rendah. Hal ini menunjukkan bahwa siswa mampu menaati segala peraturan-peraturan yang sudah ditetapkan oleh pihak sekolah (11).

Gambaran religiusitas ditinjau secara spesifik melalui dimensi-dimensinya. Dimensi keyakinan menunjuk pada seberapa tingkat keyakinan muslim terhadap kebenaran ajaran agama- 
agamanya. Terutama terhadap ajaran yang bersifat fundamental dan dogmatik (11). Berdasarkan hasil penelitian berada pada tingkat religius yang tinggi atau baik sebanyak 192 siswa $(49,6 \%)$. Hal ini menunjukkan bahwa subjek meyakini dan mempercayai hal-hal yang sifatnya fundamental dan dogma dalam agama. Sebisa mungkin mereka menghindari perbuatan-perbutaan yang dilarang oleh agama. Karena mereka percaya setiap perbuatannya akan dihubungkan dengan kehidupan alam akhirat yang bersifat abadi. Begitu juga ketika mereka dihadapkan pada fenomena kenakalan-kenakalan yang disebabkan oleh remaja, karena kenakalan remaja adalah perbuatan yang melanggar perintah agama (7).

Hasil penelitian lain menunjukkan bahwa tidak ada perbedaan religiusitas dan dimensi-dimensi religiusitas antara pria dan wanita. menunjukkan bahwa tidak ada perbedaan sifat religiusitas antara pria dan wanita. Hal ini memberi indikasi bahwa seiring dengan kemajuan jaman, anak wanita tidak lagi diperlakukan secara berbeda oleh orang dewasa di sekitarnya, khususnya dalam pembinaan kehidupan beragamnya (12).

Menurut hasil penelitian lain secara parsial, ditemukan $t$ antara religiusitas dengan kecenderungan kenakalan remaja $=-3,632$ dan $r$ parsial $=-0,346$, dengan $p=0,000(p<0,01)$, berarti ada hubungan sangat signifikan antara religiusitas dan kecenderungan kenakalan remaja. Artinya semakin tinggi religiusitas maka semakin rendah kecenderungan kenakalan remaja (12). Kenakalan remaja adalah kecenderungan remaja untuk melakukan tindakan yang melanggar aturan yang dapat mengakibatkan keru- gian dan kerusakan baik terhadap dirinya sendiri maupun orang lain yang dilakukan remaja rentang usia 13-17 tahun. Remaja yang berperilaku nakal diindikasikan memiliki tingkat religiusitas yang rendah dan kontrol diri yang rendah (13).

Menurut Glock dan Strak (14) religiusitas individu sebagai komitmen dan ketaatan individu terhadap agamanya, artinya menyatunya nilai-nilai agama yang dianut kedalam diri individu sehingga membentuk perilaku sehari-hari. Norma-norma dan nilai-nilai mengajarkan individu untuk dapat jujur dalam aspek kehidupan, salah satunya jujur dalam mengerjakan ujian atau tugas. Individu yang taat dalam agama dan perilaku sesuai dengan ajaran agama mampu membentengi diri terhadap perilaku-perilaku yang dilarang oleh agama termasuk perilaku kenakalan karena dapat merugikan diri sendiri maupun individu lain. Menurut peneliti bahwa siswa yang memiliki harga diri tinggi, beberapa bentuk kenakalan remaja anak sekolah akan mempengaruhi sejauh mana siswa menggunakan potensi yang dimiliki, seberapa yakin siswa terhadap kemampuan yang dimiliki, dan memandang dirinya berguna, bermanfaat serta sadar atas kelebihan dan kekurangan yang ada dalam diri (15). Sejalan dengan teori Frey dan Carlock (16) bahwa harga diri yang tinggi memiliki ciri-ciri seperti menghargai dan menghormati dirinya, cendrung tidak menjadi perfect, mengenali keterbatasanya dan berharap untuk tumbuh. Sedangkan, harga diri rendah memiliki kecendrungan menolak dirinya dan kurang puas.

Hasil penelitian yang menggambarkan hasil dengan tidak adanya hubungan dan perbedaan antara tingkat religius dengan tingkat kenakalan remaja baik berdasarkan jenis kelamin, usia dan kelas di sekolah SMK YBKP3 Garut, hal ini menurut peneliti dikarenakan penerapan aturan sekolah yang mudah difahami dan mudah diaplikasikan siswa sehingga resiko resiko terjadinya kenakalan remaja anak sekolah dapat dihindari atau diminimalisir. Selain itu berdasarkan hasil pengamatan peneliti selama di sekolah, bahwa sekolah tersebut menerapkan bimbingan konseling dengan materi keagamaan dan di aplikasikan dalam kehidupan sehari hari selama proses pembelajaran, contohnya memberlakukan berdoa dan membaca surat surat dalam AlQuran sebelum dan sesudah pembelajaran selesai serta dengan ditunjang kegiatan mingguan yaitu setiap hari jumat dilakukan solat sunat dhuha bersama yang dilanjutkan dengan ceramah keagamaan. Hal lain disekolah selalu melakukan keseimbangan kegiatan ekstra kulikuler yang bersifat akademik dengan kegiatan kegiatan keagamaan.

Kegiatan kegiatan yang dilakukan di sekolah tersebut sudah tertata dan terbiasa dilakukan sesuai dengan kemampuan siswa yang bekerja sama dengan staf pendidikan sekolah disesuaikan dengan tahapan perkembangan usia peserta didik yang di inventarisir dengan 
tingkatan kelas nya masing masing, terutama penelusuran minat dan bakat dari masing-masing siswa, sehingga yang dilakukan para siswa sudah sesuai dengan minat dan bakatnya juga kemampuan sesuai usianya masing-masing dalam mengembangkan kreatifitas remaja anak sekolah.

\section{Kesimpulan}

Kesimpulan yang didapat adalah tingkat religius siswa yang didapatkan adalah tinggi atau baik sebanyak 192 siswa (49,6\%). Hal ini menunjukkan bahwa subjek meyakini dan mempercayai hal-hal yang sifatnya fundamental dan dogma dalam agama. Sebisa mungkin mereka menghindari perbuatan-perbutaan yang dilarang oleh agama. Karena mereka percaya setiap perbuatannya akan dihubungkan dengan kehidupan alam akhirat yang bersifat abadi.

Begitu juga ketika mereka dihadapkan pada fenomena kenakalan-kenakalan yang disebabkan oleh remaja, karena kenakalan remaja adalah perbuatan yang melanggar perintah agama. Sehingga pada hasil uji statistik didapatkan tidak adanya hubungan dan perbedaan antara tingkat religiusitas dengan kenakalan remaja anak sekolah. Hal ini ditentukan oleh kondisi situasi lingkungan sekolah dan penerapan tatanan yang sudah tertata yang di aplikasikan langsung oleh siswa dalam menyikapai kenakalan remaja dan peningkatan tingkat religiusitas.

Rekomendasi untuk institusi sekolah diharapkan selalu mempertahankan tatanan-tatanan yang sudah diaplikasikan dengan baik, dan perlu dikembangkan untuk memperbaiki segala kekurangan dan kesalahan dalam upaya mencegah terjadinya kenakalan remaja anak sekolah.

\section{Daftar Pustaka}

1. Fajarini, U. (2019) 'Patologi Sosial Dan Dampaknya Terhadap Remaja', Jurnal Harkat: Media Komunikasi Gender. Doi: 10.15408/harkat.v15i1.13444.

2. Sarwono, S. W. (2011) Psikologi Remaja Edisi Revisi, Psikologi Remaja. doi: 10.1108/09513551011032482.Bastian.

3. Putra, A. R. B. (2015) 'Peran Guru Bimbingan Konseling Mengatasi Kenakalan Remaja di Sekolah', Pedagogik: Jurnal Pendidikan. doi: 10.33084/pedagogik.v10i1.597.

4. Iqbal, M. (2014) 'Penanggulangan Perilaku Menyimpang (Studi Kasus SMA Negeri 1 Pomalaa Kab. Kolaka Sulawesi Tenggara)', Lentera Pendidikan: Jurnal Ilmu Tarbiyah dan Keguruan. doi: 10.24252/lp.2014v17n2a6.

5. Rosyidah, F. N. and Nurdin, M. F. (2018) 'Perilaku Menyimpang: Media Sosial Sebagai Ruang Baru Dalam Tindak Pelecehan Seksual Remaja', Jurnal Pemikiran dan Penelitian Sosiologi.

6. Putri, C. D. S., Haryono, B. and Slamet, Y. (2018) 'Pengaruh Pengawasan Guru Dan Religiusitas Siswa Terhadap Perilaku Seks Pranikah Siswa SMA di Karanganyar', Jurnal Profesi Keguruan.

7. Nasikhah, D. and Prihastuti, D. (2013) 'Hubungan antara Tingkat Religiusitas dengan Perilaku Kenakalan Remaja pada Masa Remaja Awal', Jurnal Psikologi Pendidikan dan Perkembangan.

8. Beely Jovan Sumakul (2016) 'Peranan Komunikasi Keluarga Dalam Pembentukan Identitas Remaja Di Kelurahan Malalayang I Kecamatan Malalayang Kota Manado', e-journal "Acta Diurna".

9. Sigalingging, G. and Sianturi, I. A. (2019) 'Hubungan Teman Sebaya Dengan Perilaku Seksual Remaja Di SMK Medan Area Medan Sunggal', Darma agung husada.

10. Puspitaningrum, D. et al. (2016) 'Pengaruh Konsep Diri Remaja Dengan Perilaku Pencegahan Seks Bebas Di Smp "Z" Semarang', Pengaruh Konsep Diri Remaja Dengan Perilaku Pencegahan Seks Bebas Di Smp 'Z' SEMARANG.

11. Palupi, A. O. (2013) ‘Pengaruh Religiusitas Terhadap Kenakalan Remaja Pada Siswa Kelas VIII SMP Negeri 02 Slawi Kabupaten Tegal', Skripsi.

12. Aviyah, E. and Farid, M. (2014) 'Religiusitas, Kontrol Diri dan Kenakalan Remaja', Persona:Jurnal Psikologi Indonesia. doi: 10.30996/persona.v3i02.376.

13. Suidah, H. (2017) 'Hubungan Pemahaman Tingkat Agama (Religiusitas) Dengan Perilaku Seks Bebas Pada Remaja Di SMAN 1 Bangsal Mojokerto', Jurnal Keperawatan \& Kebidanan - 
Stikes Dian Husada Mojokerto.

14. Syed Alwi, S. F. and Kitchen, P. J. (2014) 'Projecting corporate brand image and behavioral response in business schools: Cognitive or affective brand attributes?', Journal of Business Research. doi: 10.1016/j.jbusres.2014.06.020.

15. Nanda Gita Lestari (2019) 'Efektivitas Konseling Kognitif Perilaku Dengan Teknik Restrukturisasi Kognitif Untuk Mengurangi Kecemasan Peserta Didik Saat Presentasi Di Mts Ismaria Al- Qur'aniyyah Bandar Lampung Tahun 2018/2019', Universitas Islam Negeri Raden Intan, Lampung. doi: 10.1017/CB09781107415324.004.

16. Utami (2019) 'Hubungan Harga Diri dan Religiusitas dengan Perilaku Menyontek Pada Siswa', Skripsi. 